\title{
Climate, Not Atmospheric Deposition, Drives the Biogeochemical Mass-Balance of a Mountain Watershed
}

\author{
Jared Heath · Jill S. Baron
}

Received: 14 January 2013/Accepted: 8 July 2013/Published online: 1 August 2013

(C) The Author(s) 2013. This article is published with open access at Springerlink.com

\begin{abstract}
Watershed mass-balance methods are valuable tools for demonstrating impacts to water quality from atmospheric deposition and chemical weathering. Owen Bricker, a pioneer of the mass-balance method, began applying mass-balance modeling to small watersheds in the late 1960s and dedicated his career to expanding the literature and knowledge of complex watershed processes. We evaluated long-term trends in surfacewater chemistry in the Loch Vale watershed, a 660-ha. alpine/subalpine catchment located in Rocky Mountain National Park, CO, USA. Many changes in surface-water chemistry correlated with multiple drivers, including summer or monthly temperature, snow water equivalent, and the runoff-to-precipitation ratio. Atmospheric deposition was not a significant causal agent for surface-water chemistry trends. We observed statistically significant increases in both concentrations and fluxes of weathering products including cations, $\mathrm{SiO}_{2}, \mathrm{SO}_{4}{ }^{2-}$, and $\mathrm{ANC}$, and in inorganic $\mathrm{N}$, with inorganic $\mathrm{N}$ being primarily of atmospheric origin. These changes are evident in the individual months June, July, and August, and also in the combined June, July, and August summer season. Increasingly warm summer temperatures are melting what was once permanent ice and this may release elements entrained in the ice, stimulate chemical weathering with enhanced moisture availability, and stimulate microbial nitrification. Weathering rates may also be enhanced by sustained water availability in high snowpack years. Rapid change in the flux of weathering products and inorganic $\mathrm{N}$ is the direct and indirect result of a changing climate from warming temperatures and thawing cryosphere.
\end{abstract}

J. Heath $(\bowtie) \cdot$ J. S. Baron

Natural Resource Ecology Laboratory, Colorado State University,

Fort Collins, CO 80523-1499, USA

e-mail: jared.heath@colostate.edu; jheath@fcgov.com

Present Address:

J. Heath

Water Product Division, City of Fort Collins Utilities,

Fort Collins, CO 80521, USA

J. S. Baron

Fort Collins Science Center, United States Geological Survey, Fort Collins, CO 80526-8118, USA 
Keywords Atmospheric deposition - Weathering - Climate change $\cdot$ Nitrogen · Snow water equivalent $\cdot$ Runoff-to-precipitation ratio

\section{Introduction}

Watershed mass-balance calculations have developed as an important technique for estimating processes resulting from interactions of water with biota, soils, and bedrock. Owen Bricker, a pioneer of the method, began applying mass-balance modeling to small watersheds in the late 1960s and dedicated his career to expanding the literature and knowledge of complex watershed processes (Bricker et al. 1968; Cleaves et al. 1970; Katz et al. 1985; Baron and Bricker 1987; Simon et al. 2005). The mass-balance approach was developed to monitor the flux of water and associated dissolved and suspended chemicals from weathering and atmospheric deposition. Loch Vale Watershed (LVWS) in Rocky Mountain National Park, CO (Fig. 1), was instrumented in 1983 with Owen Bricker's help to address the response of an alpine and subalpine ecosystem to atmospheric deposition and climate (Baron 1992).

Previous LVWS mass-balance studies have provided insight into mineral weathering sources and rates, the fate of atmospherically deposited solutes, and internal biogeochemical cycling. Base cations, silica, and alkalinity are derived from weathering of biotite gneiss that is composed of the minerals apatite, quartz, plagioclase, microcline, biotite, microcrystalline calcite, and sillimanite within the watershed (Baron and Bricker 1987;

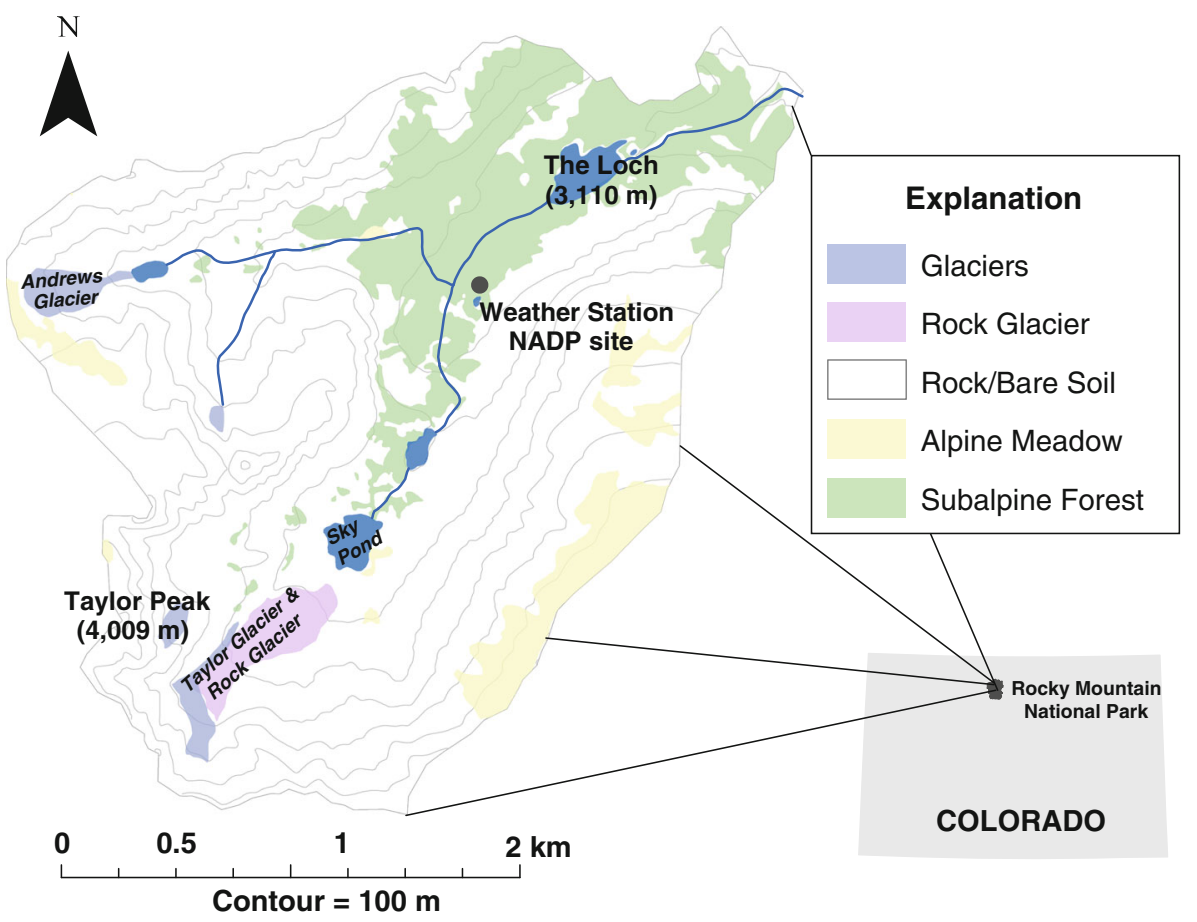

NAD 83 UTM Zone $13 \mathrm{~N}$

Fig. 1 Map of 660-hectare Loch Vale Watershed located in Rocky Mountain National Park, CO 
Mast et al. 1990; Price et al. 2013). Price et al. (2013) found over their 24-year period of study that weathering of calcite accounts for 40-65\% of the contribution of $\mathrm{Ca}^{2+}$ to the watershed, while oligoclase and apatite account for 25 and 10-35\%, respectively. Wet deposition is a primary source for the relatively conservative species chloride $\left(\mathrm{Cl}^{-}\right)$, sulfate $\left(\mathrm{SO}_{4}^{2-}\right)$, and nitrate $\left(\mathrm{NO}_{3}{ }^{-}\right)$(Baron et al. 1995; Clow and Drever 1996; Baron and Campbell 1997; Campbell et al. 2000). Isotopic analysis of dissolved $\mathrm{SO}_{4}^{2-}$ in LVWS also identified an internal mineral source (Mast et al. 1990; Kester et al. 2003). Ammonium $\left(\mathrm{NH}_{4}{ }^{+}\right)$inputs from deposition exceed outputs and almost all $\mathrm{NH}_{4}{ }^{+}$is rapidly nitrified or consumed (Campbell et al. 1995, 2000; Williams et al. 1996).

Recent studies in LVWS suggest that changes in climate and atmospheric deposition are altering the mass balance of major dissolved elements (Baron et al. 2009). Trends in wet deposition reported by the National Atmospheric Deposition Program National Trends Network (NADP/NTN) show an increase in inorganic nitrogen $(\mathrm{N})$ in precipitation throughout most of the United States since approximately 1980, while $\mathrm{SO}_{4}{ }^{2-}$ has declined sharply (Lehmann et al. 2005). Increases in wet N deposition also occurred in the Rocky Mountains of the western United States, but there is no long-term (1984-2010) significant increase in wet N deposition in LVWS (Morris et al. 2012). The annual wet $\mathrm{N}$ deposition rate in LVWS exhibited high variability prior to 1995 ; from 1995 to 2010 , wet $\mathrm{N}$ deposition was about $3.0 \mathrm{~kg} \mathrm{~N}^{-1}$ $\mathrm{yr}^{-1}$ (Morris et al. 2012). In spite of steady wet $\mathrm{N}$ deposition inputs, annual $\mathrm{N}$ export from LVWS has increased since 2000, suggesting either an internal source of $\mathrm{N}$ or that the inputs and outputs are not in annual balance (Baron et al. 2009). Wet $\mathrm{SO}_{4}{ }^{2-}$ deposition has decreased over time, but increasing $\mathrm{SO}_{4}{ }^{2-}$ concentrations in LVWS surface waters imply increased mineral weathering (Mast et al. 1990; Kester et al. 2003; Baron et al. 2009).

The Rocky Mountain climate has changed in recent years (Ray et al. 2008). Summer and autumn temperatures in the Front Range of Colorado showed statistically significant warming trends from 1991 to 2006 and the increase in summer temperatures has been associated with increasing July temperatures (Baron et al. 2009; McGuire et al. 2013). Mean and minimum July temperatures in LVWS increased by 0.22 and $0.18{ }^{\circ} \mathrm{C} \mathrm{yr}^{-1}$ from 1991 to 2006, respectively, and this trend was statistically significant (Baron et al. 2009). Warmer temperatures can increase weathering rates, influence the timing of snowmelt (Knowles et al. 2006), and alter the proportion of precipitation that falls as snow or rain (Stewart et al. 2005).

Glacier and other ice feature ablation rates increase as climate warms. Alpine glaciers are retreating worldwide in response to warming (Fountain et al. 2012). Alpine catchments occupied by active glaciers may yield weathering rates greater than the global mean (Anderson et al. 1997), and changes to the cryosphere can influence the flux of water, weathering products, nutrients, and organic matter in mountainous environments (Baron et al. 2009; Bogdal et al. 2009; Saros et al. 2010; Singer et al. 2012). We evaluated long-term trends in surface-water chemistry in LVWS to try to apportion the cause of changes in solute flux over time. We compared the long-term surface-water chemical time series with the time series of atmospheric deposition, air temperature, precipitation, and snow water equivalent (SWE). We also addressed the possible indirect climate effects from warming-induced ice ablation.

\section{Site Description}

Loch Vale watershed is a 660-hectare alpine/subalpine catchment in Rocky Mountain National Park, CO (Fig. 1), that was established to address the response of watershed-scale ecosystem processes to atmospheric deposition and climate change (Baron 1992; Baron et al. 2000; Campbell et al. 2000). It ranges in elevation from 4,009 $\mathrm{m}$ at the continental 
divide to $3,110 \mathrm{~m}$ at the outlet of The Loch, the lowest elevation subalpine lake. Fully $80 \%$ of LVWS is exposed rock and talus, and $3 \%$ of talus may cover rock glaciers (Baron 1992; Clow et al. 2003). Other land cover includes $1 \%$ permanent snow and ice, $11 \%$ alpine, $6 \%$ old-growth conifer forest, and $1 \%$ wetlands. The climate is high-mountain continental with $105 \mathrm{~cm}$ of mean annual (1984-2012) precipitation, about $20 \mathrm{~cm}$ of which falls during the summer months. Mean annual (1984-2012) temperature is $1.4{ }^{\circ} \mathrm{C}$ and summer temperatures average $11.6^{\circ} \mathrm{C}$ (http://www.nrel.colostate.edu/projects/lvws/data. html). Long-term Natural Resource Conservation Service Snow Telemetry (SNOTEL) data at Bear Lake, the nearest snow measurement site, show that average peak SWE of $50 \mathrm{~cm}$ occurred on April 25 for the period 1979-2010 (http://www.wcc.nrcs.usda.gov/nwcc/ site? sitenum=322\&state $=$ co). Discharge from 1984 to 2010 measured at The Loch outlet averaged $79 \mathrm{~cm} \mathrm{yr}^{-1}$ (http://www.nrel.colostate.edu/projects/lvws/data.html).

\section{Methods}

We compared trends in surface-water chemical concentrations and fluxes with trends in air temperature, precipitation amount, SWE, and wet deposition chemistry. Seasonal water sampling with weekly summer sample collection began in 1983. Weekly year-round sampling of surface waters at The Loch outlet began in 1991 and continues to present. Annual trends are presented from 1991 to 2010. We used the longer (1983-2010) record for June, July, and August and summer (combined June, July, and August). Since no trends were observed for other months or seasons, these results are not reported. All data were reported for water years (WY) October 1 through September 30.

Surface-water samples collected at The Loch outlet were analyzed following standard procedures (http://www.nrel.colostate.edu/projects/lvws/data.html). Data quality assurance procedures included field blanks, field duplicates, charge balance calculations, and comparisons between theoretical conductance and measured conductance (Allstott et al. 1999; Botte and Baron 2004; Richer and Baron 2011). Export was calculated by multiplying weekly concentrations of individual solutes by weekly discharge. Weekly export loads were summed for the year, summer, and June, July, and August to yield watershed outputs in kilograms per hectare per year $\left(\mathrm{kg} \mathrm{ha}^{-1} \mathrm{yr}^{-1}\right)$. Data reported here include the sum of base cations $\left(\mathrm{Ca}^{2+}, \mathrm{Mg}^{2+}, \mathrm{Na}^{+}, \mathrm{K}^{+}\right), \mathrm{SO}_{4}{ }^{2-}$, inorganic $\mathrm{N}, \mathrm{Cl}^{-}$, acid-neutralizing capacity (ANC), and dissolved silica $\left(\mathrm{SiO}_{2}\right)$.

Precipitation chemistry and amount have been measured at the National Atmospheric Deposition Program/National Trends Network (NADP/NTN) CO98 Loch Vale site (http:// nadp.sws.uiuc.edu/sites/siteinfo.asp?id=CO98\&net=NTN) located at an elevation of 3,159 $\mathrm{m}$ since 1983. Data reported in this study included precipitation amount, the sum of base cations, $\mathrm{SO}_{4}{ }^{2-}$, inorganic $\mathrm{N}$, and $\mathrm{Cl}^{-}$.

Daily temperature was measured at the Loch Vale Main Weather Station (http://co. water.usgs.gov/lochvale/data.html). Snow water equivalent was taken from the Bear Lake SNOTEL site (http://www.wcc.nrcs.usda.gov/nwcc/site?sitenum=322\&state=co). Runoffto-precipitation ratios (R:P) were calculated from measured discharge at The Loch outlet (http://www.nrel.colostate.edu/projects/lvws/data.html) and measured NADP precipitation at the CO98 site (http://nadp.sws.uiuc.edu/sites/siteinfo.asp?id=CO98\&net=NTN). We assumed inter-annual comparability in catch efficiency. Precipitation measurements in snow-dominated mountain environments are always subject to uncertainty, but the analysis of overall error of NADP measurements from colocated samplers, including several 
mountainous sites, concluded the magnitude of error in sample volume is of minor environmental significance to data users (Wetherbee et al. 2005).

\subsection{Trends in Long-Term Data}

The Mann-Kendall test (MKT) was used to evaluate trends in wet deposition and surfacewater chemical fluxes and concentrations. The MKT was performed using annual, summer, and June, July, and August data using a statistical package from Helsel et al. (2006). Statistical significance was determined to the $95 \%$ confidence interval $(p \leq 0.05)$ and noted with an asterisk in tables and figures. In the "Results" and "Discussion" sections below, significance is used to denote statistical significance with $95 \%$ confidence.

\subsection{Kendall Rank Correlation Test}

The Kendall rank correlation test was used to determine the statistical significance of correlations between climatic variables, including temperature, runoff-to-precipitation ratio (R:P), and peak SWE, with observed trends in water chemistry at The Loch outlet. Kendall's tau measures the monotonic strength of association between two independent nonparametric variables that exhibit skewness around a general trend (Helsel and Hirsch 2002). Correlations can either be described as positively correlated when Kendall's tau is positive, negatively correlated when Kendall's tau is negative, or no correlation when Kendall's tau is zero. Statistical significance was determined to the $95 \%$ confidence interval $(p \leq 0.05)$ and noted with an asterisk in tables and figures.

\section{Results}

\subsection{Wet Deposition Trends}

Analysis of 1991-2010 annual wet deposition showed no significant temporal trends for cations or inorganic $\mathrm{N}$ (Table 1). There was, however, a significant decline of $\mathrm{SO}_{4}{ }^{2-}, \mathrm{H}^{+}$, and $\mathrm{Cl}^{-}$(Table 1). Annual $\mathrm{SO}_{4}{ }^{2-}$ deposition decreased by $0.12 \mathrm{~kg} \mathrm{ha}^{-1} \mathrm{yr}^{-1}$, annual $\mathrm{H}^{+}$

Table 1 Annual wet deposition and water chemistry flux trends from Mann-Kendall trend test results for WY1991-2010 in LVWS, Rocky Mountain National Park, CO

\begin{tabular}{|c|c|c|c|c|c|c|}
\hline \multirow[t]{2}{*}{ Solute } & \multicolumn{3}{|l|}{ Wet deposition } & \multicolumn{3}{|l|}{ Loch outlet flux } \\
\hline & Trend $\left(\mathrm{kg} \mathrm{ha}^{-1} \mathrm{yr}^{-1}\right)$ & $P$ value & Trend & Trend $\left(\mathrm{kg} \mathrm{ha}^{-1} \mathrm{yr}^{-1}\right)$ & $P$ value & Trend \\
\hline Cations & 0.08 & 0.098 & Increasing & 0.17 & 0.284 & Increasing \\
\hline Inorg. $\mathrm{N}$ & 0.00 & 0.897 & No trend & 0.03 & 0.330 & Increasing \\
\hline $\mathrm{SO}_{4}^{2-}$ & -0.12 & 0.003 & Decreasing* & 0.16 & 0.098 & Increasing \\
\hline $\mathrm{H}^{+}$ & $-2.79 \mathrm{E}-03$ & 0.008 & Decreasing* & $-1.84 \mathrm{E}-04$ & 0.002 & Decreasing* \\
\hline $\mathrm{Cl}^{-}$ & -0.02 & 0.007 & Decreasing* & 0.02 & 0.153 & Increasing \\
\hline $\mathrm{SiO}_{2}$ & $\mathrm{n} / \mathrm{a}$ & $\mathrm{n} / \mathrm{a}$ & $\mathrm{n} / \mathrm{a}$ & 0.15 & 0.284 & Increasing \\
\hline $\mathrm{ANC}$ & $\mathrm{n} / \mathrm{a}$ & $\mathrm{n} / \mathrm{a}$ & $\mathrm{n} / \mathrm{a}$ & 0.23 & 0.183 & Increasing \\
\hline
\end{tabular}

Statistically significant trends $(p \leq 0.05)$ are noted with an asterisk. Silica and ANC are not measured in wet deposition 
deposition decreased by $2.79 \times 10^{-3} \mathrm{~kg} \mathrm{ha}^{-1} \mathrm{yr}^{-1}$, and annual $\mathrm{Cl}^{-}$deposition decreased by $0.02 \mathrm{~kg} \mathrm{ha}^{-1} \mathrm{yr}^{-1}$ (Table 1 ).

\subsection{Surface-Water Chemistry Trends}

Using annual resolution, there was no significant trend over time in the 1991-2010 fluxes of weathering materials or inorganic $\mathrm{N}$, except for $\mathrm{H}^{+}$, which decreased by $1.84 \times 10^{-4}$ $\mathrm{kg} \mathrm{ha}^{-1} \mathrm{yr}^{-1}$ (Table 1). The fluxes of all solutes increased during the summer months from 1984 to 2010, however, some significantly (Fig. 2). The greatest flux increase was observed in June for the cations, $\mathrm{SO}_{4}{ }^{2-}$, and ANC.

Not all trends were significant. Cation flux trends were not significant for June and July, in spite of an increase in summer flux (Table 2). The summer total cation flux was driven primarily by an August increase of $0.05 \mathrm{~kg} \mathrm{ha}^{-1} \mathrm{yr}^{-1}$ (Fig. 2a; Table 2). The change in $\mathrm{SO}_{4}{ }^{2-}$ flux was insignificant in July, but strong and significant increases of 0.11 and $0.04 \mathrm{~kg} \mathrm{ha}^{-1} \mathrm{yr}^{-1}$ in June and August, respectively, provided a significant summer trend (Fig. 2b; Table 2). Acid-neutralizing capacity increased over time, with a summer increase
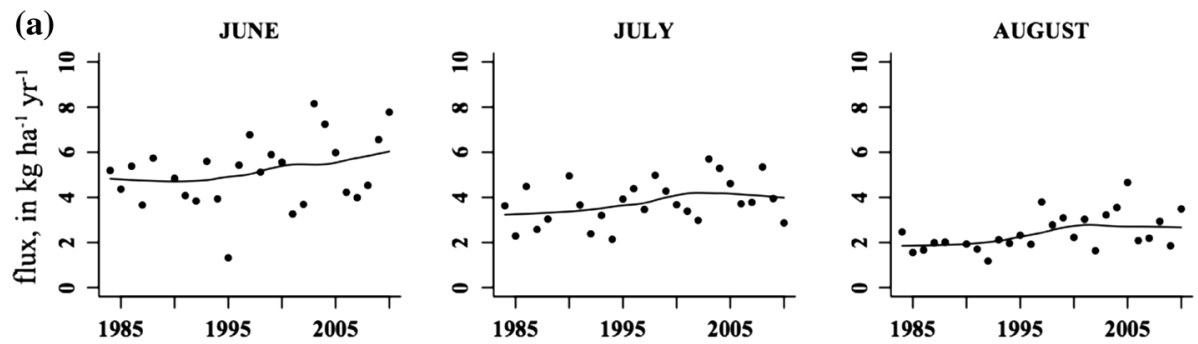

(b)
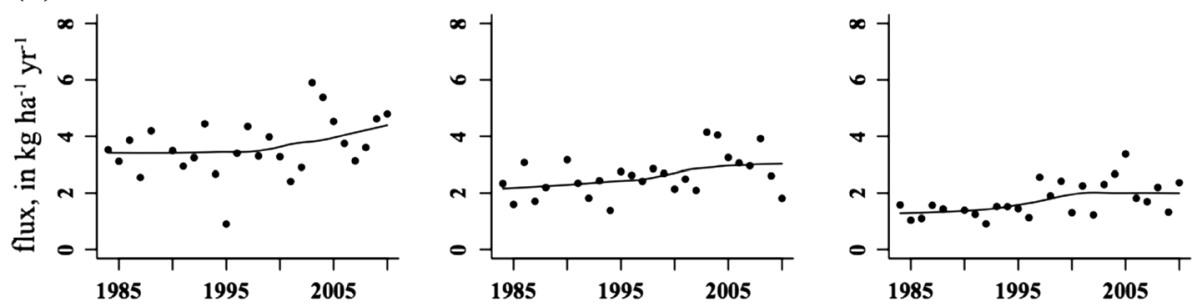

(c)
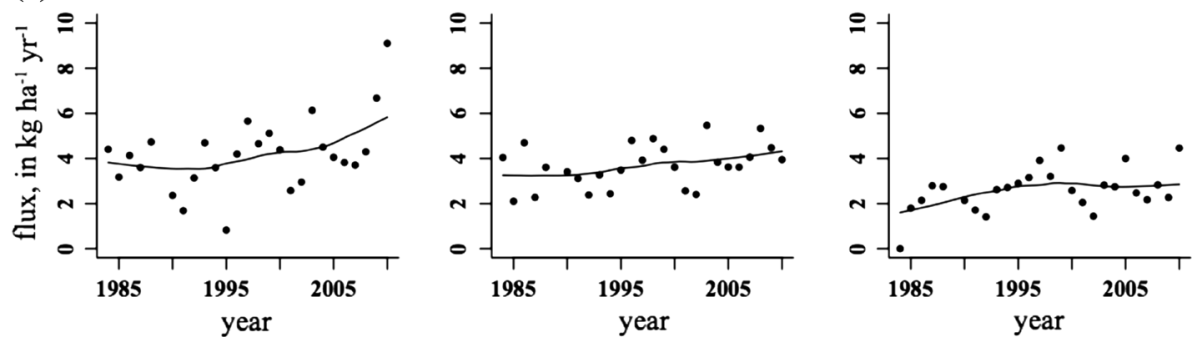

Fig. 2 June, July, and August water chemistry flux in LVWS, Rocky Mountain National Park, CO, from 1984 to 2010 with smooth curve fitted by loess (locally weighted polynomial regression) for a cations, b $\mathrm{SO}_{4}{ }^{2-}$, and c ANC 
Table 2 Summer, June, July, and August water chemistry flux and concentration trends from MannKendall test results for WY1984-2010 from LVWS, Rocky Mountain National Park, CO

\begin{tabular}{|c|c|c|c|c|c|c|c|}
\hline \multirow[t]{2}{*}{ Solute } & \multirow[t]{2}{*}{ Time period } & \multicolumn{3}{|l|}{ Flux } & \multicolumn{3}{|l|}{ Concentration } \\
\hline & & $\begin{array}{l}\text { Trend } \\
\left(\mathrm{kg} \mathrm{ha}^{-1} \mathrm{yr}^{-1}\right)\end{array}$ & $P$ value & Trend & $\begin{array}{l}\text { Trend } \\
\left(\mathrm{mg} \mathrm{l}^{-1} \mathrm{yr}^{-1}\right)\end{array}$ & $P$ value & Trend \\
\hline \multirow[t]{4}{*}{ Cations } & Summer & 0.13 & 0.028 & Increasing* & 0.02 & 0.005 & Increasing* \\
\hline & June & 0.05 & 0.146 & Increasing & 0.02 & 0.004 & Increasing* \\
\hline & July & 0.04 & 0.086 & Increasing & 0.02 & 0.004 & Increasing* \\
\hline & August & 0.05 & 0.018 & Increasing* & 0.06 & 0.022 & Increasing* \\
\hline \multirow[t]{4}{*}{$\mathrm{SO}_{4}^{2-}$} & Summer & 0.02 & 0.017 & Increasing* & 0.02 & 0.017 & Increasing* \\
\hline & June & 0.11 & 0.012 & Increasing* & 0.02 & 0.028 & Increasing* \\
\hline & July & 0.04 & 0.058 & Increasing & 0.02 & 0.007 & Increasing* \\
\hline & August & 0.04 & 0.016 & Increasing* & 0.04 & 0.016 & Increasing* \\
\hline \multirow[t]{4}{*}{ ANC } & Summer & 0.13 & 0.087 & Increasing & 0.02 & 0.004 & Increasing* \\
\hline & June & 0.07 & 0.113 & Increasing & 0.02 & 0.001 & Increasing* \\
\hline & July & 0.04 & 0.028 & Increasing* & 0.02 & 0.003 & Increasing* \\
\hline & August & 0.03 & 0.103 & Increasing & 0.02 & 0.006 & Increasing* \\
\hline \multirow[t]{4}{*}{$\mathrm{SiO}_{2}$} & Summer & 0.20 & 0.015 & Increasing* & 0.01 & 0.033 & Increasing* \\
\hline & June & 0.09 & 0.086 & Increasing & 0.02 & 0.007 & Increasing* \\
\hline & July & 0.02 & 0.402 & Increasing & 0.01 & 0.134 & Increasing \\
\hline & August & 0.03 & 0.156 & Increasing & 0.03 & 0.156 & Increasing \\
\hline \multirow[t]{4}{*}{ Inorg. $\mathrm{N}$} & Summer & 0.02 & 0.058 & Increasing & $3.27 \mathrm{E}-03$ & 0.086 & Increasing \\
\hline & June & $4.53 \mathrm{E}-03$ & 0.428 & Increasing & $2.58 \mathrm{E}-03$ & 0.103 & Increasing \\
\hline & July & $6.17 \mathrm{E}-03$ & 0.158 & Increasing & $3.20 \mathrm{E}-03$ & 0.04 & Increasing* \\
\hline & August & $7.64 \mathrm{E}-03$ & 0.009 & Increasing* & 0.01 & 0.009 & Increasing* \\
\hline \multirow[t]{4}{*}{$\mathrm{Cl}^{-}$} & Summer & 0.01 & 0.052 & Increasing & 0.00 & 0.108 & No trend \\
\hline & June & $4.68 \mathrm{E}-03$ & 0.158 & Increasing & $1.50 \mathrm{E}-03$ & 0.134 & Increasing \\
\hline & July & $3.14 \mathrm{E}-03$ & 0.086 & Increasing & $1.08 \mathrm{E}-03$ & 0.139 & Increasing \\
\hline & August & $2.56 \mathrm{E}-03$ & 0.104 & Increasing & $2.56 \mathrm{E}-03$ & 0.104 & Increasing \\
\hline
\end{tabular}

Statistically significant trends $(p \leq 0.05)$ are noted with an asterisk

of $0.13 \mathrm{~kg} \mathrm{ha}^{-1} \mathrm{yr}^{-1}$, but the only significant flux trend occurred in July (Table 2). The summer increase in $\mathrm{SiO}_{2}$ flux of $0.20 \mathrm{~kg} \mathrm{ha}^{-1} \mathrm{yr}^{-1}$ was significant, but the trends were not significant for any individual month (Table 2). Finally, even though there was an increase in the amount of inorganic $\mathrm{N}_{\text {and }} \mathrm{Cl}^{-}$flux over time, the only significant increase was for inorganic $\mathrm{N}$ in August (Table 2).

The concentrations of nearly all solutes increased significantly in all summer months from 1984 to 2010 (Table 2). The exceptions were $\mathrm{SiO}_{2}$, inorganic $\mathrm{N}$, and $\mathrm{Cl}^{-}$, whose trends were significant in some, but not all, months. A significant summer increase in $\mathrm{SiO}_{2}$ concentration was driven by June values. Concentrations of inorganic $\mathrm{N}$ increased in all months, but the rate of increase, which was slight, was only significant in July and August. The increase in $\mathrm{Cl}^{-}$concentrations over time was very small and insignificant (Table 2).

We compared the solute flux with environmental drivers to get an idea of causes for increasing flux over time from LVWS. All solute fluxes for all time periods were positively 
correlated with average maximum July temperature, R:P, and peak SWE at The Loch outlet (except for annual $\mathrm{Cl}^{-}$flux, August $\mathrm{SO}_{4}{ }^{2-}$ flux, and all inorganic $\mathrm{N}$ flux with peak SWE), but not all correlations were significant (Table 3). The flux of different solutes displayed almost unique responses to different drivers. The annual cation flux correlated significantly with R:P, while June and July cation fluxes correlated significantly with peak SWE. August cation flux was significantly related to average maximum July temperatures. Annual $\mathrm{SO}_{4}{ }^{2-}$ flux correlated positively with average maximum July temperatures and $\mathrm{R}: \mathrm{P}$. Acid-neutralizing capacity and $\mathrm{SiO}_{2}$ fluxes were significantly correlated with peak SWE annually and for June and July. July $\mathrm{SiO}_{2}$ flux was also significantly correlated with $\mathrm{R}: \mathrm{P}$. Annual, June, and July inorganic N fluxes were significantly correlated with R:P, while the August inorganic N flux was most strongly correlated with maximum July temperatures. Chloride fluxes were not significantly related to any driver. None of the solutes showed a significant correlation with wet deposition (Table 3).

Table 3 Correlations of annual, June, July, and August solute fluxes with average maximum July temperatures, runoff-to-precipitation ratios (R:P), peak snow water equivalent (SWE), and wet deposition using Kendall rank correlations for WY1991-2010

\begin{tabular}{|c|c|c|c|c|c|}
\hline Solute flux & Season & Avg. Max July Temp. & $\mathrm{R}: \mathrm{P}$ & Peak SWE & Wet deposition \\
\hline \multirow[t]{4}{*}{ Cations } & Annual & + & $+^{*}$ & + & - \\
\hline & June & N/A & + & $+^{*}$ & \\
\hline & July & + & + & $+^{*}$ & \\
\hline & August & $+^{*}$ & + & + & \\
\hline \multirow{4}{*}{$\mathrm{SO}_{4}{ }^{2-}$} & Annual & $+^{*}$ & $+^{*}$ & + & - \\
\hline & June & N/A & + & + & \\
\hline & July & + & + & + & \\
\hline & August & + & + & 0 & \\
\hline \multirow[t]{4}{*}{ ANC } & Annual & + & + & $+^{*}$ & N/A \\
\hline & June & N/A & + & $+^{*}$ & \\
\hline & July & + & + & $+^{*}$ & \\
\hline & August & + & + & + & \\
\hline \multirow[t]{4}{*}{$\mathrm{SiO}_{2}$} & Annual & + & + & $+^{*}$ & N/A \\
\hline & June & N/A & + & $+^{*}$ & \\
\hline & July & + & $+^{*}$ & $+^{*}$ & \\
\hline & August & + & + & + & \\
\hline \multirow[t]{4}{*}{ Inorg. $\mathrm{N}$} & Annual & $+^{*}$ & $+^{*}$ & + & + \\
\hline & June & N/A & $+^{*}$ & + & \\
\hline & July & + & $+^{*}$ & + & \\
\hline & August & $+^{*}$ & + & - & \\
\hline \multirow[t]{4}{*}{$\mathrm{Cl}^{-}$} & Annual & + & + & 0 & - \\
\hline & June & N/A & + & + & \\
\hline & July & + & + & + & \\
\hline & August & + & + & + & \\
\hline
\end{tabular}

June flux values were not compared with July temperatures. Positive correlations are noted with a plus sign $(+)$; negative correlations are noted with a minus sign $(-)$; and no correlation is noted with a zero $(0)$. Statistically significant trends $(p \leq 0.05)$ are noted with an asterisk 


\subsection{Comparison of Flux in Extreme Years}

We calculated the mean annual flux for all solutes for the warmest and coolest Julys, highest and lowest R:P years, and wettest (highest SWE) and driest (lowest SWE) years in order to gain insight into causal agents of change. Extremes were defined as the five lowest and five highest years for average maximum July temperatures, R:P, and peak SWE (Fig. 3; Table 4). The Mann-Whitney $U$ test was used to determine whether the two extremes (lowest and highest) came from the same distribution.

There were greater annual fluxes of $\mathrm{SiO}_{2}, \mathrm{ANC}, \mathrm{SO}_{4}{ }^{2-}$, and cations in LVWS in years with the warmest July temperatures, but the increases were not statistically significant (Fig. 3a; Table 4). Years with the highest $\mathrm{R}: \mathrm{P}$ produced more $\mathrm{SiO}_{2}, \mathrm{ANC} \mathrm{Cl}^{-}, \mathrm{SO}_{4}{ }^{2-}$, and cations compared to years with the lowest R:P, and the difference was significant for $\mathrm{SiO}_{2}$ and cations (Fig. 3b). Years with the highest R:P had an average annual production of $18.67(\mathrm{SD}=2.69)$ $\mathrm{kg}$ cations $\mathrm{ha}^{-1} \mathrm{yr}^{-1}$ and $18.37(\mathrm{SD}=0.97) \mathrm{kg} \mathrm{SiO}_{2} \mathrm{ha}^{-1} \mathrm{yr}^{-1}$. The years with the lowest R:P had an annual average production of $11.91(\mathrm{SD}=1.38) \mathrm{kg}$ cations $\mathrm{ha}^{-1} \mathrm{yr}^{-1}$ and 12.79 $(\mathrm{SD}=1.24) \mathrm{kg} \mathrm{SiO}_{2} \mathrm{ha}^{-1} \mathrm{yr}^{-1}$ (Table $4 \mathrm{~b}$ ). In high R:P years, significantly less inorganic $\mathrm{N}$ was retained $\left(0.20(\mathrm{SD}=0.82) \mathrm{kg} \mathrm{N} \mathrm{ha}^{-1} \mathrm{yr}^{-1}\right)$ in the watershed than years when the R:P was low $\left(1.61(\mathrm{SD}=0.67) \mathrm{kg} \mathrm{N} \mathrm{ha}^{-1} \mathrm{yr}^{-1}\right)$. Years with the highest peak SWE resulted in greater net flux of cations, inorganic $\mathrm{N}, \mathrm{ANC}$, and $\mathrm{SiO}_{2}$ in $\mathrm{LVWS}$ compared to years with the lowest peak SWE, but the differences were not statistically significant (Fig. 3c; Table 4).

The R:P ratio is related to July maximum temperatures (Fig. 4). The average R:P was 0.77 from 1984 to 2010, suggesting slightly more than $23 \%$ of precipitation was evaporated, transpired, or sublimated. Runoff approached or exceeded precipitation with R:P of 0.90 , $0.89,1.00,1.16,0.88$, and 0.95, respectively, in water years 1998, 1999, 2000, 2003, 2005, and 2006 (Fig. 4a). Average maximum July temperatures were significantly and positively correlated with annual R:P $(p=0.034)$, suggesting that July temperatures influence the amount of discharge. In most years when the R:P was greater than average, the autumn (September, October, November) discharge was also greater than average (Fig. 4b).

Table 4 Comparison of the mean and standard deviation annual flux, in $\mathrm{kg} \mathrm{ha}^{-1} \mathrm{yr}^{-1}$, for the five coolest versus warmest years, lowest runoff-to-precipitation ratio (R:P) versus highest R:P years, and driest (low peak SWE) versus wettest years (high peak SWE)

\begin{tabular}{|c|c|c|c|c|c|c|c|c|c|c|c|c|}
\hline \multirow[t]{2}{*}{ a) } & \multicolumn{6}{|c|}{ Warmest maximum July temperatures } & \multicolumn{6}{|c|}{ Coldest maximum July temperatures } \\
\hline & Cations & $\mathrm{SO}_{4}{ }^{2-}$ & Inorg. $\mathrm{N}$ & $\mathrm{Cl}^{-}$ & ANC & $\mathrm{SiO}_{2}$ & Cations & $\mathrm{SO}_{4}{ }^{2-}$ & Inorg.N & $\mathrm{Cl}^{-}$ & ANC & $\mathrm{SiO}_{2}$ \\
\hline Average & 16.08 & 8.96 & -0.42 & 0.71 & 16.45 & 15.56 & 12.16 & 5.47 & -1.29 & -0.03 & 14.57 & 11.94 \\
\hline SD & 5.89 & 4.97 & 1.11 & 0.44 & 4.29 & 4.67 & 1.06 & 1.92 & 0.76 & 0.73 & 2.87 & 2.34 \\
\hline \multirow[t]{2}{*}{ b) } & \multicolumn{6}{|l|}{ High R:P } & \multicolumn{6}{|c|}{ Low R:P } \\
\hline & Cations & $\mathrm{SO}_{4}{ }^{2-}$ & Inorg.N & $\mathrm{Cl}^{-}$ & ANC & $\mathrm{SiO}_{2}$ & Cations & $\mathrm{SO}_{4}{ }^{2-}$ & Inorg.N & $\mathrm{Cl}^{-}$ & ANC & $\mathrm{SiO}_{2}$ \\
\hline Average & 18.67 & 10.00 & -0.20 & 0.88 & 19.30 & 18.37 & 11.91 & 5.69 & -1.61 & 0.28 & 16.81 & 12.79 \\
\hline SD & 2.69 & 3.57 & 0.82 & 0.25 & 1.05 & 0.97 & 1.38 & 3.13 & 0.67 & 1.01 & 2.62 & 1.24 \\
\hline \multirow[t]{2}{*}{ c) } & \multicolumn{6}{|c|}{ High peak SWE } & \multicolumn{6}{|c|}{ Low peak SWE } \\
\hline & Cations & $\mathrm{SO}_{4}{ }^{2-}$ & Inorg.N & $\mathrm{Cl}^{-}$ & ANC & $\mathrm{SiO}_{2}$ & Cations & $\mathrm{SO}_{4}{ }^{2-}$ & Inorg.N & $\mathrm{Cl}^{-}$ & ANC & $\overline{\mathrm{SiO}_{2}}$ \\
\hline Average & 15.05 & -1.09 & 6.69 & 0.36 & 18.64 & 14.37 & 11.97 & -1.10 & 6.41 & 0.57 & 13.49 & 11.03 \\
\hline SD & 2.30 & 0.26 & 1.20 & 0.19 & 1.78 & 4.93 & 2.00 & 0.34 & 1.10 & 0.48 & 3.88 & 2.36 \\
\hline
\end{tabular}


Fig. 3 Comparison of means for the five most extreme years: a coolest versus warmest maximum July temperatures; b lowest R:P (runoff-toprecipitation ratio) versus highest $\mathrm{R}: \mathrm{P}$; and $\mathbf{c}$ driest (low peak SWE) versus wettest (high peak SWE). Error bars depict standard deviation

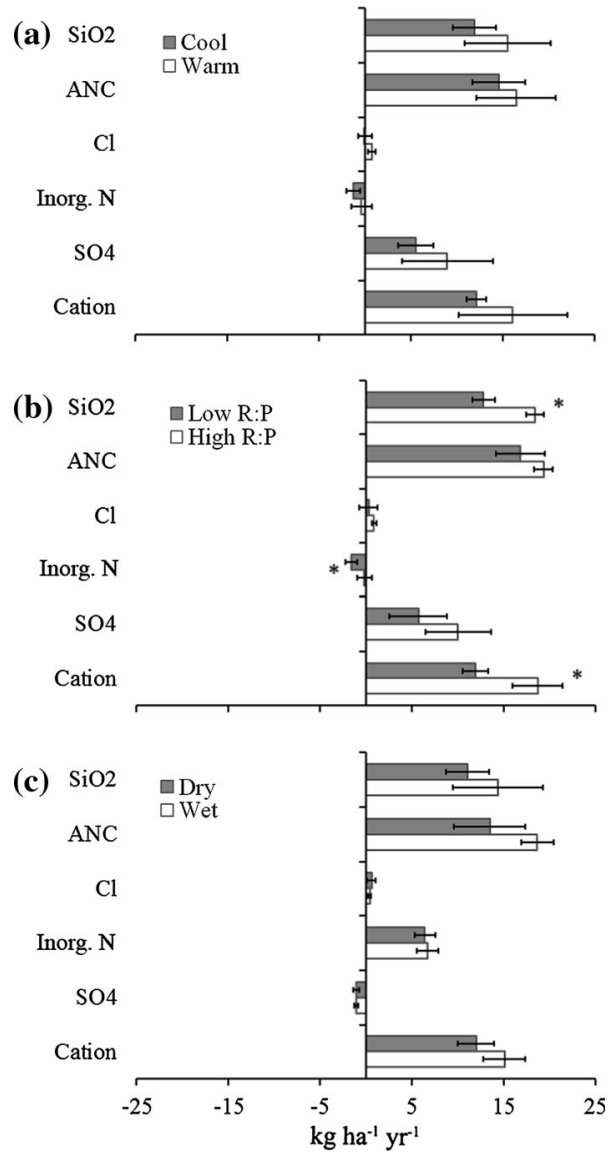

\section{Discussion}

Surface-water chemistry in LVWS is changing significantly during the summer months. This was not apparent using an annual time step, but is obvious in strong summer increases in weathering products and inorganic N. Annual fluxes in LVWS, as in other highmountain watersheds with seasonal snowpacks, are dominated by snowmelt. Snowmelt drives the annual hydrograph and annual flux values, and while it may indirectly influence weathering rates, as discussed below, our observed changes in summer flux are too small to influence the annual totals.

There were significant increases in the summer fluxes and concentrations of cations, $\mathrm{SiO}_{2}, \mathrm{SO}_{4}{ }^{2-}$, and $\mathrm{ANC}$, and in inorganic $\mathrm{N}$ over time. Surprisingly, none of the trends were statistically correlated with wet atmospheric deposition. Instead, LVWS solute concentrations and flux were correlated with average maximum July temperature, R:P, and SWE. The greatest increases over time in concentrations and fluxes at The Loch outlet occurred in July and August. Hydrologically, this is commensurate with the receding hydrograph and return to base flow, as has been shown for other alpine catchments (e.g., Williams and Melack 1991). Late summer is also the time of maximum cryosphere thaw. We observed this with LVWS R:P ratios in warm years, and it matches theoretical constructs posed by 

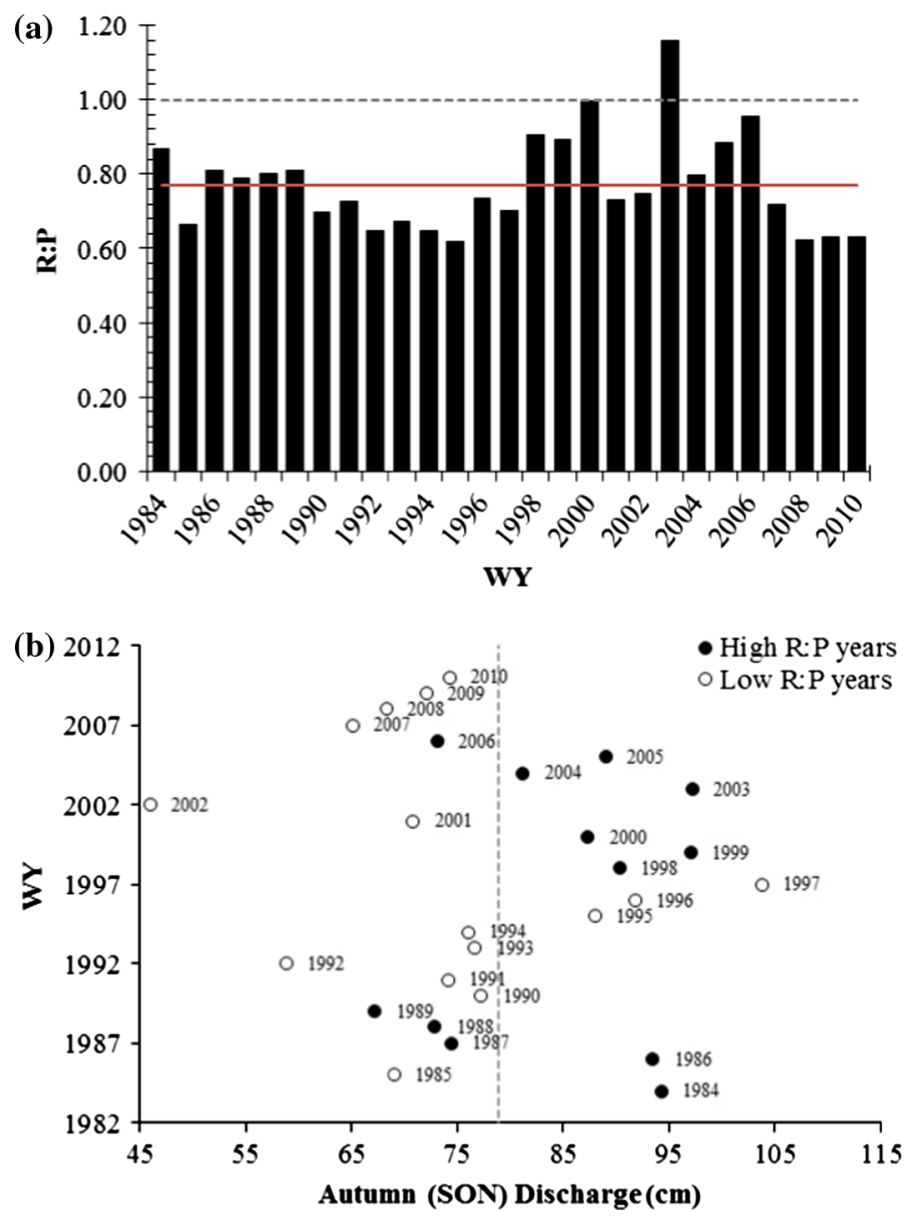

Fig. 4 Time-series column plot of a the annual runoff-to-precipitation ratio (R:P) in LVWS for water years (WY) 1984 to 2010. The red line depicts the average annual R:P, while the black dashed line represents when runoff equals precipitation inputs; and $\mathbf{b}$ Autumn cumulative discharge for above average R:P years (solid circles) and below average R:P years (hollow circles). The gray dashed line represents average autumn discharge for LVWS

Clow et al. (2003) and Williams et al. (2006), which suggest increasing contributions of glacier, rock glacier, and permafrost melt to mountain streams as the $0{ }^{\circ} \mathrm{C}$ isotherm increases in elevation.

The increase in runoff in higher R:P years is much greater than can be accounted for entirely by glacial melt from small headwater glacial remnants. While some runoff may come from melting ice, high R:P may be more related to the snowmelt rate, with warm summer temperatures leading to more rapid melt and thus more runoff export instead of subsurface storage. The presence of liquid water in talus and block fields, or in newly thawed substrates, may enhance chemical weathering of calcite and apatite that are exposed by mechanical weathering (Mast et al. 1990, 1992; Price et al. 2013). Hall et al. (2002) suggested chemical weathering in cold environments is limited by moisture availability rather than temperature. Under this framework, it is possible that warm Julys increase the water available for mineral dissolution by thawing glacial ice or seasonal snow. In years of high SWE, seasonal snow 
persists longer into the summer, providing meltwater later in the summer season. Anderson et al. (1997) found chemical weathering in glacial environments to be relatively high, as have others in more recent studies (Williams et al. 2006; Saros et al. 2010; Caine 2010). Cation, $\mathrm{SiO}_{2}$, and ANC fluxes were positively correlated with peak SWE during June and July, the months that often correspond with spring snowmelt, suggesting a relationship between years with high snowfall and water chemical composition.

The source of some solutes coming from the cryosphere could include dry deposition in the form of dust or enhanced chemical weathering caused by prolonged moisture contact with rock as described above. Bulk snowpack chemistry data from the USGS Rocky Mountain Snowpack Chemistry Network (http://co.water.usgs.gov/projects/RM_ snowpack/index.html) reveal cation concentrations in the LVWS snowpack have been increasing since 1993. A 2006 dust event covered much of the Rocky Mountains, including LVWS, resulting in a 10-fold increase in $\mathrm{Ca}^{2+}$ and 100-fold increase in ANC compared to early- and late-season snow (Rhoades et al. 2010). The concentration of cations in the LVWS snowpack in 2006 was 24.2 meq L ${ }^{-1}$, while a similar dust event in 2008 resulted in a concentration of 26.6 meq $\mathrm{L}^{-1}$. Neff et al. (2008) suggested that dust loads increased by $500 \%$ following western settlement of the United States during the nineteenth century. In recent decades, the San Juan Mountains in southern Colorado experience up to seven large dust deposition events every year. Based on these studies, there is no doubt that episodic dust events add minerals to the snowpack and that the occurrence of these events is increasing. However, the importance of these events on LVWS water quality is unknown.

We previously hypothesized that increased late summer inorganic $\mathrm{N}$ flux could be the result of some combination of $\mathrm{N}$ released from melting ice and enhanced microbial nitrification rates (Baron et al. 2009). Recent research suggests both mechanisms are plausible. Saros et al. (2010) found higher concentrations of nitrate $\left(\mathrm{NO}_{3}{ }^{-}\right)$in glacial meltwater compared to seasonal snow meltwater in the central and northern Rocky Mountains, and ice samples from two Front Range glaciers in 2012 contained considerable inorganic N (J.S. Baron, unpublished data). Even a small input of melting ice may affect water chemistry in warm years when rapid snowmelt leads to more runoff and export. Microbial nitrification also occurs in periglacial environments (Wynn et al. 2007; Saros et al. 2010; Osborne 2012). As with weathering rates, it appears moisture, not temperature, may govern microbial activity in cold environments. Additional evidence of microbial nitrification comes from comparison of isotopes in $\mathrm{NO}_{3}{ }^{-}$in snowpack, snowmelt, rainfall, and surface water. During snowmelt and throughout the summer, much of the inorganic $\mathrm{N}$ in stream water bears the signature of microbial nitrification, even at the highest elevations directly below ice (Campbell et al. 2000; E.K. Hall personal communication).

\section{Conclusions}

Watershed mass-balance methods have been valuable tools for demonstrating impacts to water quality from atmospheric deposition, leading to air quality policies that have greatly improved the ecological condition of US surface waters (Likens et al. 2001; Greaver et al. 2012). Mass-balance studies have also been fundamental to our understanding the role of mineral weathering on water quality (Bricker 1986; Price et al. 2013). By exploring the change in mass balances over time in LVWS, we have discovered a change in summer water chemistry and export in response to warming summer temperatures and SWE. The connection between these drivers and the flux of weathering products and inorganic $\mathrm{N}$ is not necessarily direct. Warm summer temperatures and high SWE may stimulate mineral 
weathering with enhanced moisture availability, and warm summer temperatures may melt what was once permanent ice to release elements entrained therein. Moisture availability also appears to increase microbial nitrification, and all these processes likely contribute to summer season increases in LVWS chemical fluxes. There is an unknown but increasing influence of dust inputs. While long-term monitoring in instrumented watersheds has been criticized as unscientific, wasteful, and expensive, it is empirical studies such as these that increase our ability to understand and quantify cause and effect in times of rapid environmental change.

Acknowledgments Financial support was provided by the US Geological Survey and the National Park Service. Thanks to all who helped collect these data over many years, and to the National Park Service, especially Judy Visty, for long-term support. Alisa Mast, Stephanie Kampf, and Jason Price provided valuable comments that improved the paper. This paper is a product of the Western Mountain Initiative.

Open Access This article is distributed under the terms of the Creative Commons Attribution License which permits any use, distribution, and reproduction in any medium, provided the original author(s) and the source are credited.

\section{References}

Allstott EJ, Bashkin MJ, Baron JS (1999) Quality assurance report, Loch Vale Watershed Study, 1995-1998. USGS Open-File Report 99-111

Anderson SP, Drever JI, Humphrey NF (1997) Chemical weathering in glacial environments. Geology 25(5):399-402

Baron JS (ed) (1992) Biogeochemistry of a subalpine ecosystem: Loch Vale Watershed. Ecological Studies Series 90. Springer, New York

Baron J, Bricker OP (1987) Hydrologic and chemical flux in Loch Vale Watershed, Rocky Mountain National Park. In McKnight D, Averett RC (eds) Chemical quality of water and the hydrologic cycle. Lewis Publishers, Ann Arbor, MI, pp 141-156

Baron JS, Campbell DH (1997) Nitrogen fluxes in a high elevation Rocky Mountain basin. Hydrol Process 11(7):783-799

Baron JS, Allstott EJ, Newkirk BK (1995) Analysis of long term sulfate and nitrate budgets in a Rocky Mountain basin. In: Tonnesson KA, Williams MW, Tranter M (eds) Biogeochemistry of seasonally snow-covered catchments. IASH Publication No 228: International Association of Hydrologic Sciences Press, Institute of Hydrology, Wallingford, Oxfordshire, OX10 8BB, UK, pp 255-262

Baron JS, Rueth HM, Wolfe AP, Nydick KR, Allstott EJ, Minear JT, Moraska B (2000) Ecosystem responses to nitrogen deposition in the Colorado Front Range. Ecosystems 3(4):352-368

Baron JS, Schmidt TM, Hartman MD (2009) Climate-induced changes in high elevation stream nitrate dynamics. Glob Change Biol 15:1777-1789

Bogdal C, Schmid P, Zennegg M, Anselmetti FS, Scheringer M, Hungerbühler K (2009) Blast from the past: melting glaciers as a relevant source for persistent organic pollutants. Environ Sci Technol 43(21):8173-8177

Botte JA, Baron J (2004) Quality assurance report, Loch Vale Watershed, 1999-2002. USGS Open-File Report 2004-1306

Bricker OP (1986) Geochemical investigations of selected Eastern United States watersheds affected by acid deposition. J Geol Soc 143:621-626

Bricker OP, Godfrey AE, Cleaves ET (1968) Mineral-water interaction during the chemical weathering of silicates. In: Baker RA (ed) Advances in chemistry, vol 73. American Chemical Society, USA, pp 128-142

Caine N (2010) Recent hydrologic change in a Colorado alpine basin: an indicator of permafrost thaw? Ann Glaciol 51(56):130-134

Campbell DH, Baron JS, Tonnessen K, Brooks P, Schuster P (2000) Controls on nitrogen flux in alpine/ subalpine watersheds. Water Resour Res 36(1):37-48

Campbell DH, Clow DW, Ingersoll GP, Mast MA, Spahr NE, Turk JT (1995) Processes controlling the chemistry of two snowmelt-dominated streams in the rocky mountains. Water Resour Res 31(11):2811-2821 
Cleaves ET, Godfrey AE, Bricker OP (1970) Geochemical balance of a small watershed and its geomorphic implications. Geol Soc Am Bull 81(10):3015-3032

Clow DW, Drever JI (1996) Weathering rates as a function of flow through an alpine soil. Chem Geol 132:131-141

Clow DW, Schrott L, Webb R, Campbell DH, Torizzo A, Dornblaser M (2003) Ground water occurrence and contributions to streamflow in an alpine catchment. Colorado Front Range. Ground Water 41(7):937-950

Fountain AG, Campbell JL, Schuur EAG, Stammerjohn SE, Williams MW, Ducklow HM (2012) The disappearing cryosphere: impacts and ecosystem responses to rapid cryosphere loss. Bioscience 62(4):405-415

Greaver TL, Sullivan T, Herrick JD, Barber M, Baron J, Cosby B, Deerhake M, Dennis R, Dubois JJD, Goodale C, Herlihy A, Lawrence G, Liu L, Lynch J, Novak K (2012) Ecological effects from nitrogen and sulfur air pollution in the United States: what do we know? Front Ecol Environ 7:365-372

Hall K, Thorn CE, Matsuoka N, Prick A (2002) Weathering in cold regions: some thoughts and perspectives. Prog Phys Geogr 26(4):577-603

Helsel DR, Hirsch RM (2002) Statistical methods in water resources techniques of water resources investigations, Book 4, chapter A3. U.S. Geological Survey. http://pubs.usgs.gov/twri/twri4a3/

Helsel DR, Mueller DK, Slack JR (2006) Computer program for the Kendall family of trend tests. U.S. Geological Survey Scientific Investigations Report 2005-5275, 4 pp. http://pubs.usgs.gov/sir/2005/ 5275/pdf/sir2005-5275.pdf

Katz BG, Bricker OP, Kennedy MM (1985) Geochemical mass-balance relationships for selected ions in precipitation and stream water, Catoctin Mountains, MD. Am J Sci 285:931-962

Kester CL, Baron JS, Turk JT (2003) Isotopic study of sulfate sources and residence times in a subalpine watershed. Environ Geol 43(5):606-613

Knowles N, Dettinger MD, Cayan DR (2006) Trends in snowfall versus rainfall in the Western United States. J Clim 19:4545-4559

Lehmann CMB, Bowersox VC, Larson SM (2005) Spatial and temporal trends of precipitation chemistry in the United States. Environ Pollut 135(3):347-361

Likens GE, Butler TJ, Buso DC (2001) Long-and short-term changes in sulfate deposition: effects of the 1990 Clean Air Act Amendments. Biogeochemistry 52(1):1-11

Mast AM, Drever JI, Baron JS (1990) Chemical weathering in the Loch Vale watershed, Rocky Mountain National Park, Colorado. Water Resour Res 26(12):2971-2979

McGuire CR, Nufio CR, Bowers MD, Guralnick RP (2013) Elevation-dependent temperature trends in the Rocky Mountain Front Range: changes over a 56- and 20-year record. PlosOne 7(9):e44370. doi:10. 1371/journal.pone.0044370

Morris K, Mast A, Clow D, Wetherbee G, Baron J, Taipale C, Blett T, Gay D, Richer E (2012) 2010 monitoring and tracking wet nitrogen deposition at Rocky Mountain National Park: August 2012. Natural Resource Report NPS/NRSS/ARD/NRR-2012/562. National Park Service, Denver, CO

Neff JC, Ballantyne AP, Farmer GL, Mahowald NM, Conroy JL, Landry CC, Overpeck JT, Painter TH, Lawrence CR, Reynolds RL (2008) Increasing eolian dust deposition in the western United States linked to human activity. Nat Geosci 1:189-195

Osborne B (2012) The effects of temperature and moisture on alpine microbial processes across a gradient of soil development. Master's thesis, Colorado State University, Fort Collins

Price JR, Peresolak K, Brice RL, Tefend KS (2013) Temporal variability in the chemical weathering of $\mathrm{Ca}^{2+}$-bearing phases in the Loch Vale Watershed, Colorado, USA: a mass-balance approach. Chem Geol 342:151-166

Ray AJ, Barsugli JJ, Averyt KB, Wolter K, Hoerling M (2008) Colorado climate change: a synthesis to support water resource management and adaptation, a report for the Colorado Water Conservation Board by the NOAA-CU Western Water Assessment. http://wwa.colorado.edu/publications/reports/ WWA_ClimateChangeColoradoReport_2008.pdf

Rhoades C, Elder K, Greene E (2010) The influence of an extensive dust event on snow chemistry in the southern Rocky Mountains. Arct Antarct Alp Res 42(3):98-105

Richer EE, Baron JS (2011) Loch Vale Watershed long-term ecological research and monitoring program: quality assurance report, 2003-2009. USGS Open-File Report 2011-1137

Saros JE, Rose KC, Clow DW, Stephens VC, Nurse AB, Arnett HA, Stone JR, Williamson CE, Wolfe AP (2010) Melting high alpine glaciers enrich lakes with reactive nitrogen. Environ Sci Technol 44(13):4891-4896

Simon NS, Bricker OP, Newell W, McCoy J, Morawe R (2005) The distribution of phosphorus in Popes Creek, VA, and in the Pocomoke River, MD: two watersheds with different land management practices in the Chesapeake Bay Basin. Water Air Soil Pollut 164:189-204 
Singer GA, Fasching C, Wilhelm L, Niggemann J, Steier P, Dittmar T, Battin TJ (2012) Biogeochemically diverse organic matter in Alpine glaciers and its downstream fate. Nat Geosci 5(10):710-714

Stewart IT, Cayan DR, Dettinger MD (2005) Changes toward earlier stream flow timing across western North America. J Clim 18:1136-1155

Wetherbee GA, Latysh NE, Gordon JD (2005) Spatial and temporal variability of the overall error of National Atmospheric deposition program measurements determined by the USGS collocated-sampler program, water years 1989-2001. Environ Pollut 135(3):407-418

Williams MW, Melack JM (1991) Solute chemistry of snowmelt and runoff in an alpine basin. Sierra Nevada. Water Resour Res 27(7):1575-1588

Williams MW, Baron JS, Caine N, Sommerfeld R, Sanford R Jr (1996) Nitrogen saturation in the Rocky Mountains. Environ Sci Technol 30:640-646

Williams MW, Knauf N, Caine N, Lui F, Verplanck PL (2006) Geochemistry and source waters of rock glacier outflow, Colorado Front Range. Permafrost Periglac Process 17:13-33

Wynn PM, Hodson AJ, Heaton THE, Chenery SR (2007) Nitrate production beneath a high arctic glacier, Svalbard. Chem Geol 244(1-2):88-102 